\title{
The Problem of "können" in Kant's B-Deduction and Its Significance for Fichte
}

Michihito Yoshime

\section{(2) OpenEdition \\ Journals}

Electronic version

URL: http://journals.openedition.org/ref/914

DOI: $10.4000 /$ ref.914

ISSN: 2258-014X

Publisher

EuroPhilosophie Editions

Electronic reference

Michihito Yoshime, "The Problem of "können" in Kant's B-Deduction and Its Significance for Fichte », Revista de Estud(i)os sobre Fichte [Online], 17 | 2018, Online since 01 December 2018, connection on 08 September 2020. URL : http://journals.openedition.org/ref/914 ; DOI : https://doi.org/10.4000/ref.914

This text was automatically generated on 8 September 2020

(C) EuroPhilosophie 


\title{
The Problem of "können" in Kant's B-Deduction and Its Significance for Fichte
}

\author{
Michihito Yoshime
}

\section{Introduction: What is the problem of können?}

1 The opening passage of $\$ 16$ of the Transcendental Deduction section in the second edition of Critique of Pure Reason is one of the most famous from Kant's entire works. Namely:

It must be possible for the 'I think' to accompany all my representations; for otherwise something would be represented in me which could not be thought at all, and that is equivalent to saying that the representation would be impossible, or at least would be nothing to me (B131-132; Kemp Smith [1929] 2007, pp. 152-153). ${ }^{1}$

2 This translation by Norman Kemp Smith seems more precise and explicit in its interpretation of the first sentence compared to the vague implication of the original German text:

Das: Ich denke, muß alle meine Vorstellungen begleiten können... (B131)

3 First, Kemp Smith omitted Kant's stress on 'Ich denke' and 'können'. ${ }^{2}$ Additionally, and more importantly, he chose 'be possible' as the translation for 'können', while there are other possible candidates here. This becomes clearer if compared with, for instance, the following recent translations:

The I think must be capable of accompanying all my presentations... (B131; Pluhar 1996, p. 177).

The I think must be able to accompany all my representations... (B131; Guyer and Wood 1998, p. 246)

It is understandable that a number of different translations have been employed for 'können'. Due to differences in the syntactic rules for auxiliary verbs between German and English, if 'können' were simply replaced with the English equivalent, namely, 'can', this would yield a solecism. However, this would make no difference given that 
Kant's use of können would not substantially change the meaning of this text. In that case, what Kant intended to express in this passage would remain the same with or without this auxiliary verb or, at the very least, this use of können would not be inconsistent with his conclusion regarding the characteristics of the transcendental apperception in the A-deduction. Additionally, you can remove this auxiliary verb from the sentence without causing any solecism.

Still, it should be noted that this opening sentence is not the only one where Kant uses 'können'. In actuality, he repeats similar modal expressions right up until the next section, whereas the corresponding parts of the A-deduction seldom have it. Above all, he emphasizes the word können by spacing it out as he spaces out Ich denke. As the latter is the key phrase of the entire section, the former is also likely to be important to him.

Thus, it is likely that he actually added some substantial meaning with the word können. Apparently, it suggests that he changed his view on pure apperception from that of the A-deduction because, there, he had consistently argued concerning "transcendental (or pure, original) apperception" involving not the necessity of possibility, but the necessity itself of one and the same self-consciousness, in which the threefold synthesis of the manifold should be accomplished. If this is the case, this auxiliary verb should constitute the key to comprehending the difference between the two versions of Kant's doctrine of transcendental apperception.

While a large number of studies have been made on Kant's doctrine concerning apperception, including the meaning of können, many recent scholars do not regard it as being central to our interpretation of either edition. For example, Patricia Kitcher argues that that opening sentence is the essential point of the B-deduction, and it is the equivalent of the A-deduction's "principle of apperception," that is: "All representations must (if cognition is possible) belong to a single self-consciousness" (Kitcher 2011, p. 125).

8 However, such a simplifying reading does not seem to provide a satisfactory account of the necessity of können, which Kant himself emphasized. In this paper, therefore, I would like to focus my attention on the meaning and origin of the word können. I will do this with reference to Fichte's view on the issue. Some scholars, including Henry E. Allison, have already investigated the meaning of können within Kant's own writings. My main interest here consists, rather, in how and to what extent Fichte's view of apperception differs from that of Kant.

\section{The word können as redundant}

9 Even if different readings of the word können did not harm the consistency of Kant's argument for the necessary unity of apperception, what the notion represents should be explained. The simplest explanation is to see it as having no substantial sense, as simply being an auxiliary word used to adjust the tone of a sentence. On this reading, Kant would mean simply that the I think must actually accompany all my representations. If this is misleading, it would be because of Kant's carelessness. I do not believe that this explanation has broad support, but the classic commentary by $\mathrm{H}$. J. Paton does seem to adopt it. Paton mainly follows Kant's argument by means of the Adeduction and uses passages of the B-deduction as supplementary explanation, as 
needed. So, he apparently finds no substantial difference between them, but is a little puzzled by “Kant's usual carelessness in terminology" (Paton [1936] 2011, p. 380n4).

As for more recent works, as I see it, we can find at least two different ways to understand können. First, it could represent the nature of transcendental apperception as a function or faculty. Kant calls transcendental apperception "the function by means of which this manifold [of the representations] is synthetically combined into one cognition" (A108; Guyer and Wood 1998, 233, my supplement), "a common function of the mind for combining it in one representation," (A109; Guyer and Wood 1998, p. 233) or "the radical faculty of all our cognition" (A114; Guyer and Wood 1998, p. 236). The recent translations of können as 'be able to' or 'be capable of also seem to support such a reading. According to this reading, that the I think must be able to accompany all my representations is almost equivalent to the fact that transcendental apperception must be able to unify all my representations. And it must be able to do so, if empirical cognition is possible at all. Kant writes as follows:

[N]o cognitions can occur in us, no connection and unity among them, without that unity of consciousness that precedes all data of the intuitions, and in relation to which all representation of objects is alone possible. This pure, original, unchanging consciousness I will now name transcendental apperception (A107; Guyer and Wood 1998, p. 232).

[I]ndeed, it is through those conditions [of the necessary unity of apperception] that every cognition is first made possible (A110; Guyer and Wood 1998, p. 234, my supplement).

11 However, what makes the matter complicated here is that the modal expression of possibility rarely appears in the A-deduction. Instead, Kant argues repeatedly for the necessity of one self-consciousness, that is, for transcendental apperception:

[T] he original and necessary consciousness of the identity of oneself is at the same time a consciousness of an equally necessary unity of the synthesis of all appearances... (A108; Guyer and Wood 1998, p. 233)

All empirical consciousness...has a necessary relation to a transcendental consciousness (preceding all particular experience), namely the consciousness of myself, as original apperception. It is therefore absolutely necessary that in my cognition all consciousness belong to one consciousness (of myself) (A117n; Guyer and Wood 1998, p. 237).

12 Apparently, these passages affirm that transcendental apperception must actually unify all the representations in empirical consciousness. And given that the Adeduction could be read as consistent with the opening phrase of $\$ 16$ of the Bdeduction, we should have a basis for eliminating können. Some scholars, including Kitcher, seem to share this reading. The word können, which should represent the function or faculty of transcendental apperception, becomes redundant once the actuality of experience is given in the argument, because then the function or faculty must have already been activated. And this actuality is, in fact, presupposed by Kant as the starting point of the whole argument of CPR. His chief concern in this is, of course, how synthetic a priori propositions (as cognition) are possible (cf. B73). He then assumes that logic, mathematics and pure natural science "traveled the secure path of a science" (BX; Guyer and Wood 1998, p. 107). He is not here tackling the enormous problem of whether cognition is at all possible.

13 In my opinion, however, such a reading does not provide a satisfactory account of the meaning of the word können or, strictly, Kant's emphasis on it by repeating similar 
modal expressions in the B-deduction. It seems that this auxiliary verb is not redundant.

\section{The word können as representing probability}

Another reading of the passage in question, which I would like to support, is that of understanding können as representing no more than the possibility of transcendental apperception. Henry Allison, for instance, seems to understand it in this way when he says, "Kant maintains that it must be possible, for the "I think" to accompany them [representations], even if it does not always actually do so" (Allison 2015, p. 335, my supplement). In that sense, Allison's view of the auxiliary verb looks to be near to Kemp Smith's translation, namely, 'possible', though he chose "be able" (ibid.) for his own translation of that sentence. This possibility does not represent the function or faculty and is, therefore, not redundant even under the condition that the necessity of experience is given. It, rather, represents a kind of probability of the I think that accompanies all my representations. In other words, Kant affirms, with können placed not only in the sentence at issue but also in that section and the following sections, that it is also possible for the I think not to accompany my representations. If so, then it is also understandable that Kant seems to have stressed and repeated the expression, particularly given that this is one of the most important points changed from the Adeduction. What is, then, the content of this change?

Allison emphasizes the importance of the distinction between sensibility and understanding here. According to him, Kant cannot simply argue that the I think must actually accompany all my representations, since these include sensible intuitions that are not thought (ibid, p. 337). ${ }^{3}$ In short, we are not always thinking "I, I, I....". Kant has already made what seems to be the same point in the A-deduction's stronger argument:

This [one self-] consciousness may often only be weak, so that we connect it with the generation of the representation only in the effect, but not in the act [of synthesis] itself, i.e., immediately; but regardless of these differences one consciousness must always be found, even if it lacks conspicuous clarity... (A103-104; Guyer and Wood 1998, p. 231, my supplement)

However, strictly speaking, this passage does not mean exactly the same as: "It must be possible for the 'I think' to accompany all my representations..." (B131; Kemp Smith [1929] 2007, p. 152), where this is read as expressing the probability of the I think's accompanying all my representations. In the Transcendental Dialectic of the first edition, criticizing the "Third paralogism of personality," he states:

[I]n the whole time in which I am conscious of myself, I am conscious of this time as belonging to the unity of my Self, and it is all the same whether I say that this whole time is in $\mathrm{Me}$, as an individual unity, or that I am to be found with numerical identity, in all of this time (A362; Guyer and Wood 1998, p. 423).

There he also uses the phrase "the I think accompanies - and indeed with complete identity - all representations at every time in my consciousness" (A362-363; ibid.). Thus, at least for Kant in the first edition, the lack of I think in some of my representations is not exactly the same as one and the same self-consciousness being weak at times. Kitcher, rightly, describes this contrast as the difference between "togetherness" and "mineness". According to her, what Kant tries to show is "how different mental states can be unified in a single self and not how an individual can attribute a particular mental state to himself" (Kitcher 2011, p. 124). Although she 
regards this principle as common to both editions, it seems to apply better to the Bdeduction. Certainly, Kant also refers in the B-deduction to the "same subject" (B132, Guyer and Wood 1998, p. 246) or a "universal self-consciousness" (ibid. p. 247), in which all representations are to be unified. But in the following paragraphs, in contrast to the A-deduction, he prefers the expression "the transcendental unity of apperception" to "the transcendental (or pure, original) apperception".

Thus, if one employs the second, and to me appropriate, reading that können represents probability, then the contrast between the two editions on transcendental apperception, or one and the same self-consciousness, also becomes clearer. It seems that in the B-deduction Kant revised his claim concerning transcendental apperception (one and the same self-consciousness) and the identity of the I, to a somewhat weaker or more modest one. That is, he dropped "mineness" in favor of "togetherness". This might suggest that Kant changed the focus of his argument on the issue, namely from the aspect of ratio essendi to that of ratio cognoscendi, just like he did later in his Grounding of Grounding for the Metaphysics of Morals and the second Critique (cf. Allison 2015, p. 230). ${ }^{4}$ If so, however, why did he need to make the transition? I would like to investigate the reason for this not within his own writings but, rather, with regard to Fichte's view on this issue.

\section{Why is Kant's argument unsatisfactory to Fichte?}

19 Although his Wissenschaftslehre itself was established through his meditation upon Reinhold's Elementary Philosophy and Schulze's Aenesidemus, Fichte considered himself to be a transcendental idealist, completing the work that Kant should have done. He states:

I have always said, and say it here again, that my system is no other than that of Kant. That is, it includes the same view on the matter, but it is entirely independent of Kant's account in its process (EEWL, GA I/4, 184). ${ }^{5}$

Now I know very well that Kant has never established such a system.... However, I surely believe myself as well to know that Kant might have thought such a system... and that only under this condition his claims have meaning and a relevance (ZEWL, GA I/4, 230).

In fact, Fichte often employs Kant's terms or arguments while he describes his own system, namely Wissenschaftslehre, and the I think is no exception. In Zweite Einleitung in die Wissenschaftslehre, he writes:

To all, what is thought to appear in consciousness, the I must be necessarily thought in addition. In the explanation of the determination of mind, the I must not be abstracted, or, as Kant expresses it: All my representations must be able to be accompanied, [so must] be thought as accompanied, by the I think. (ZEWL, GA I/4, 253, my supplement)

21 Here Fichte paraphrased the equivalent of Kant's sentence in the original passage without the modality of possibility. So, at a glance, he also seems to think the word können is redundant or dispensable. And he mentions this in defending his doctrine of the I and of intellectual intuition. According to Fichte, the latter is not an immediate consciousness of the thing in itself, but "of that I act, and what act I make [daß ich handle, und was ich handle]" (ibid. 216). This intellectual intuition appears in every moment of everyone's consciousness; we cannot even walk without it (cf. ibid.). 
Therefore, Fichte also seems to hold that the I think must actually accompany all my representations.

However, he also states that it is nonsense to think "I, I, I..." in all moments (cf. ibid. 253), and, though in ZEWL no other passage on this issue appears, years later in WL1812, he re-engages with können. There he states:

Kant notes that the deduction of the categories can only be the establishment of the principle of the self-relation of the consciousness, so precisely of the reflexibility.... The point of this deduction would be, namely, that it must be possible for the I think to accompany all my representations [das: Ich denke muß alle meine Vorstellungen begleiten können].... This können stands in the wrong part. It must have been: The possibility of I think accompanies necessarily all my representations (WL1812, GA II/ 13, 102-103).

According to his argument, what must be accompanying my representations is, strictly speaking, not the I think itself but the "determined reflexibility [bestimmte Reflexibilität]" (ibid. 104), which becomes I think once reflection is performed. This reflexibility must always accompany our representations, even if it remains inactivated and subtle in one's daily consciousness. The reason for this is clear: if there were no such background, then we could not explain the source of the "mineness" (Kitcher $2011,124)$ that the I think should bear. Reflection is naturally self-referential, and the presupposition that the I think comes from reflexibility correlates with Fichte's view on the I and each representation. Namely, representations are not the given but rather the end products of the mutual limitation of the I and the not I, which occurs within the absolute I (cf. GWL, GA 1/2, 369-384). As is well known, Fichte later introduced the absolute (God) on top of the absolute I, the highest principle of the Wissenschaftslehre in his Jena years. Additionally, his late writings and lectures are rather abstruse due to their metaphysical tendencies and frequent use of visual metaphors such as "image [Bild]", "seeing [Sehen]", or "light [Licht]"; for this reason, it becomes more difficult to contrast them with the arguments of other philosophers, including Kant. For instance, Fichte also notes:

It must be possible for the I think to accompany all my representations [Das Ich denke muß alle meine Vorstellungen begleiten können]. It might be true: however, in a sense, it totally disappears for us. The I accompanies all seeing, and is the original material of all seeing. (WL1812, GA II/13, 147)

We would need an account of the word seeing to fully understand this passage. Yet we can safely say that his view of the relation between the I and representations remains the same. The main point of this view consists in the idea that it "descends from the universal [i.e. the I] to the special" (BWL, GA I/3, 145, my supplement), contrary to Kant who "starts from the presupposition that a manifold is given for the possible reception to the unity of consciousness" (ibid. 144). 'I think' for Fichte is primarily an expression of spontaneity, and secondarily an expression of negativity, limitation, and receptivity. This is because the predicate 'think' is a special determination of the subject ' $I$ ' in so far as it excludes all other ways of being of the 'I' (cf. GWL, GA I/2, 298). Therefore, Fichte's view of the I think is nearer to the A-deduction than the B-deduction. He never admits the possibility of thinking of "togetherness" of the self, to which the manifold of representations should be unified, without there being a "mineness" of it. The latter is indispensable for Fichte, because it is the very source of the former.

And the reason why Kant dropped this view is, as I see it, to avoid the risk of being taken to admit intellectual intuition. Kant consistently understood intellectual 
intuition as being an immediate consciousness of the I as noumenon, that is, the thing in itself. The fact that he prefers the expression "the transcendental unity of apperception" to "the transcendental apperception" in the B-deduction also suggests the reason for his transition. As mentioned above, however, such a transition would be needed in so far as intellectual intuition, as well as the I itself, should be understood to refer to being. In this sense, Kant's philosophy of the self is somehow ontological, and so lacks a viewpoint on human acts, ${ }^{6}$ which Fichte gave in his Wissenschaftslehre. Thus, for Fichte, Kant's können is an unnecessary compromise, and could ruin the view of the $I$, which stands at the center of transcendental idealism.

\section{References}

Allison, Henry E. (2015), Kant's Transcendental Deduction, Oxford University Press.

Guyer, Paul and Wood, Allen B. (1998), Critique of Pure Reason, written by Immanuel Kant, Cambridge University Press.

Kemp Smith, Norman ([1929] 2007), Critique of Pure Reason, written by Immanuel Kant, intr. by Howard Caygill, rev. 2. ed., Palgrave Macmillan.

Kitcher, Patricia (2011), Kant's Thinker, Oxford University Press.

Paton, H. J. ([1936] 2011), Kant's Metaphysic of Experience, vol. 1, Routledge.

Pluhar, Werner S. (1996), Critique of Pure Reason, written by Immanuel Kant, intr. by Patricia Kitcher, Hackett Publishing Company, Inc.

\section{NOTES}

1. In this paper, I will refer to English translations of CPR with the name of the translator and the year of publication of each version, to distinguish them from one another. Abbreviations: $\mathrm{EEWL}=$ Erste Einleitung in die Wissenschaftslehre, 1797; GA = Gesamtausgabe der Bayerischen Akademie der Wissenschafte; GEWL = Grundriss des Eigenthümlichen der Wissenschaftslehre in Rucksicht auf das theoretische Vermögen, 1795/1802; GWL = Grundlage der gesammten Wissenschaftslehre, 1794/1802; WL1812 = Die Wissenschaftslehre [von 1812]; ZEWL = Zweite Einleitung in die Wissenschaftslehre, 1797.

2. I use italics for the words, which are spaced out or typed in boldface.

3. Allison also points out the importance of the imagination in the matter, for it is closely related with apperception, and its role is also changed from that of the A-deduction.

4. ) In the former he started from freedom to accomplish the deduction of the categorical imperative, and in the latter he introduced the consciousness of moral principle as a "fact of reason", and then claimed that this fact shows the practicality of pure reason as transcendental freedom.

5. For the translation of Fichte's writings, I take full responsibility.

6. ) A classic reading of Kant's self by Heinz Heimsoeth apparently admired this ontological tendency. On the other hand, some scholars including Friedrich Kaulbach try to interpret Kant's 
apperception as referring to the act of reason. In my opinion, the most thoroughgoing attempt at such an interpretation is made by Fichte.

\section{ABSTRACTS}

The present paper examines the problem of "können" at the very beginning of $\mathrm{KrV} \S 16$ by offering a linguistic analysis of the term in order to highlight the difference between Kant's and Fichte's views on pure apperception, self-reflection and self-consciousness. Firstly, it will be considered whether "können" is redundant in the Kantian account. Secondly, it will studied the hypothesis that this term represents probability. Thirdly, it will be discussed why Fichte finds Kant's argument to be unsatisfactory. As a conclusion, it will be argued that Kant's "können" ruins the unity of the I or subject that is central for Fichte.

INDEX

Keywords: Kant, Fichte, I, pure apperception, deduction of the categories

\section{AUTHOR}

\section{MICHIHITO YOSHIME}

Osaka University 